\title{
KETERKAITAN ANTARA PENERIMAAN PAJAK PENGHASILAN DAN PBB TERHADAP KESENJANGAN PENDAPATAN
}

\author{
Anisa Fahmi \\ nies.fahmi@gmail.com \\ Politeknik Keuangan Negara STAN
}

\begin{abstract}
ABSTRAK
Kesenjangan sosial di antara anggota masyarakat yang paling miskin dapat menyebabkan ketidakstabilan politik dan ekonomi suatu negara. Penelitian ini bertujuan untuk mengkaji hubungan antara kesenjangan pendapatan dan pertumbuhan ekonomi serta menguji pengaruh Pajak Penghasilan dan Pajak Bumi dan Bangunan terhadap kesenjangan pendapatan. Pajak adalah salah satu instrumen yang digunakan untuk memperkecil kesenjangan baik antar wilayah maupun antar kelompok pendapatan. Berdasarkan hasil analisis diperoleh kesimpulan bahwa variabel PDB, PPh, dan jumlah penduduk berpengaruh signifikan terhadap kesenjangan pendapatan. Kondisi perekonomian Indonesia saat ini masih berada pada sisi kiri dari kurva "inverted U curve". Tingginya PDB menyebabkan kesenjangan pendapatan semakin tinggi. Kondisi ini muncul karena pemerintah masih fokus mengejar pertumbuhan ekonomi. Temuan dalam penelitian juga ini menunjukkan bahwa penerimaan pajak penghasilan berpengaruh positif terhadap kesenjangan pendapatan. Hal tersebut terjadi karena kebijakan perpajakan di Indonesia lebih ditujukan untuk meningkatkan penerimaan negara, bukan sebagai alat untuk meredistribusikan kesejahteraan.
\end{abstract}

Kata kunci: kesenjangan pendapatan, pertumbuhan ekonomi, penerimaan pajak.

\begin{abstract}
Sosial inequalities among the poorest members of society causes political and economic instablility. This study aims to examine the relationship between income inequality and economic growth. It also tests the effect of income tax and property tax on income inequality. Taxes are instrument used to reduce gaps between regions or income groups. Based on the results, it was concluded that $P D B, P P h$, and population have significant effect on income inequality. Indonesian's current economic condition is still on the left side of the "inverted $U$ " curve. The high PDB causes a higher income gap. This condition arises because the government is still focused on economic growth. The findings also shows that income tax have positive effects on income inequality. This occured because indonesian tax policies is aimed to increase state revenues, not as tool redistribution.
\end{abstract}

Keywords: income disparities, economic growth, tax revenue.

\section{PENDAHULUAN}

Indonesia adalah negara kepulauan terbesar di dunia yang terdiri dari 17.508 pulau dengan karakteristik antar pulau yang berbeda-beda (UNDP Indonesia, 2018). Dengan jumlah penduduk mencapai 250 juta jiwa, sebagai negara kepulauan Indonesia dihadapkan pada tantangan dalam mewujudkan kesejahteraan seluruh masyarakat Indonesia. Perbedaan karakteristik wilayah dan sumber daya pada akhirnya menjadi penyebab utama ketimpangan baik pada pembangunan maupun pendapatan penduduk di setiap wilayah. Berdasarkan Data Produk Domestik Bruto tahun 2017, sebagian besar pendapatan nasional terdistribusikan di 
Pulau Jawa dengan kontribusi sebesar 58,49\% PDB diikuti pulau Sumatera sebesar 21,66\%, sementara sisanya yaitu 19,85\% terdistribusikan di Pulau Bali, Nusa Tenggara,Kalimantan, Sulawesi, dan Papua (BPS, 2018). Kesenjangan juga terlihat dari besarnya pendapatan perkapita penduduk antar provinsi. Dari 37 provinsi, pendapatan perkapita DKI Jakarta merupakan yang tertinggi, yaitu sebesar Rp.232,34 Juta diikuti Kalimantan Timur sebesar Rp.165,71 Juta. Sementara pendapatan perkapita Indonesia sebesar Rp. 52,79 Juta dengan pendapatan perkapita terendah Rp.17,24 Juta di Nusa Tenggara Timur.

Gambar 1. Rasio Gini Indonesia Tahun 2002 - 2017

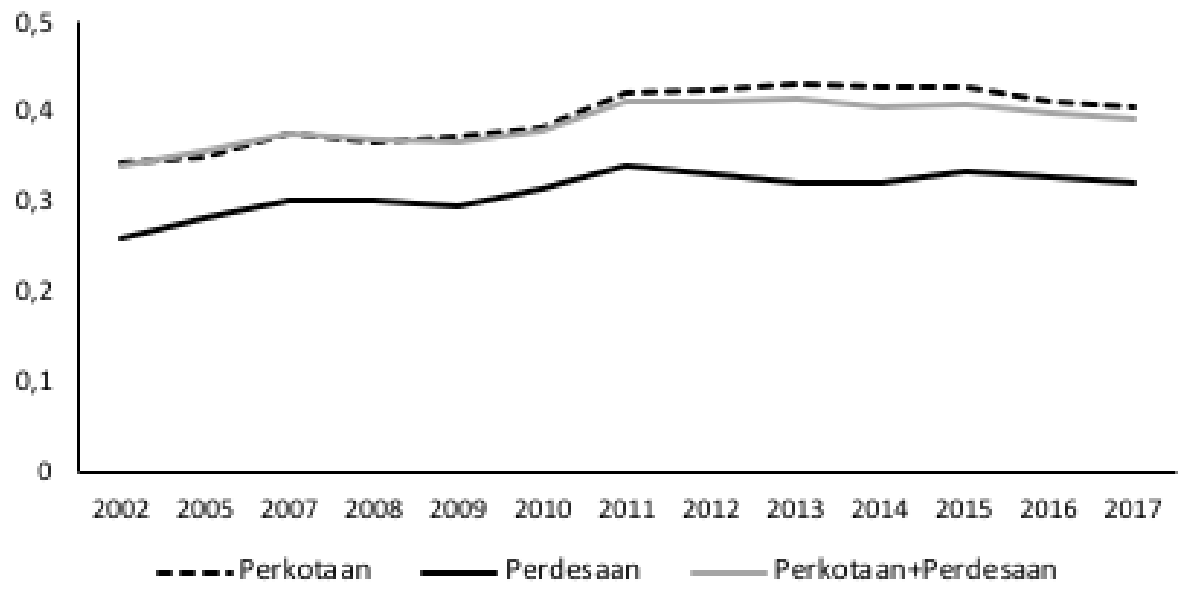

Sumber: Badan Pusat Statistik (diolah)

Kesenjangan pendapatan di Indonesia juga dapat dilihat dari rasio gini yang masih tinggi dan belum menunjukkan tren penurunan. Rasio gini mengukur kesenjangan antar kelompok pendapatan masyarakat. Berdasarkan gambar 1, rasio gini di Indonesia pada tahun 2017 berada pada angka 0,4. Kesenjangan pendapatan ini lebih besar terjadi di perkotaan dibanding perdesaan. Negara dengan rasio gini yang tinggi memiliki ketimpangan dalam masyarakat yang sangat jelas dan melemahkan kemampuan satu negara untuk tumbuh dalam jangka panjang.

Pada dasarnya, kesenjangan pendapatan antar kelompok masyarakat ini merupakan masalah yang umum terjadi di banyak negara baik di negara miskin, berkembang, bahkan di negara maju sekalipun. Karena pertumbuhan ekonomi dan kesenjangan ekonomi merupakan trade-off yang dihadapi setiap negara. Namun yang perlu mendapatkan perhatian lebih adalah, seberapa besar kesenjangan yang terjadi pada masing-masing daerah. Hasil penelitian Thornton (2001) terhadap 96 negara hubungan antara ketimpangan pendapatan dan perkembangan ekonomi mengikuti pola kurva $U$ terbalik, seperti yang dinyatakan oleh Kuznets. Demikian juga temuan Oskooee dan Gelan (2008) di negara Amerika Serikat. Penelitian mengenai kesenjangan pendapatan di Amerika Serikat juga dilakukan Rubin dan Segal (2015) yang menyimpulkan bahwa pertumbuhan ekonomi dan kesenjangan pendapatan terkait secara positif. Kesenjangan pendapatan timbul karena adanya perbedaan produktivitas. Berdasarkan model pertumbuhan Solow, produktivitas tidak hanya ditentukan oleh modal fisik tetapi juga modal manusia. Semakin baik kualitas sumber daya manusia, semakin tinggi produktivitas yang kemudian berdampak pada pendapatan yang lebih tinggi. Dengan demikian, perbedaan kualitas sumber daya menjadi salah satu penyebab timbulnya kesenjangan pendapatan. Murphy dan Topel (2016) menyatakan bahwa peningkatan ketimpangan diakibatkan oleh kegagalan investasi modal manusia dalam mengimbangi meningkatnya permintaan akan keterampilan ketika perekonomian berkembang. 
Menteri Keuangan Sri Mulyani (Kementerian Keuangan, 2017) menyatakan bahwa pajak adalah salah satu instrumen yang digunakan untuk memperkecil kesenjangan baik antar wilayah maupun antar kelompok pendapatan. Pajak menjadi sumber utama penerimaan negara yang kemudian digunakan untuk membiayai proses pembangunan, termasuk pembangunan infrastruktur. Semakin banyak penerimaan pajak, semakin banyak fasilitas dan infrastruktur yang dibangun sehingga konektivitas antar wilayah di Indonesia menjadi lebih baik. Perbaikan konektivitas antar wilayah akan menghasilkan trickle down effect melalui perluasan kesempatan kerja dan perluasan pasar.

Baer dan Galvao (2008) mengkaji keterkaitan antara beban pajak, pengeluaran pemerintah, dan distribusi pendapatan di Brazil dan menemukan bukti yang kuat bahwa beban pajak dan pengeluaran pemerintah memiliki dampak redistribusi yang rendah. Di Negara Kanada, hasil penelitian yang dilakukan Kesselman dan Cheung (2004) menemukan bahwa sistem pajak secara substansial dapat memiliki dampak redistributif jika tingkat pajak keseluruhannya tinggi. Artinya, ketimpangan pendapat akan turun jika tingkat pajak yang dikenakan lebih tinggi. Sementara di Indonesia, Kumara (2015) menyimpulkan bahwa redistribusi melalui pajak (PPh dan $\mathrm{PBB}$ ) tidak mampu memperbaiki kondisi kesenjangan pendapatan.

Berdasarkan data pajak sebagaimana diilustrasikan pada gambar 2, realisasi penerimaan pajak baik pajak penerimaan dalam negeri maupun pajak perdagangan internasional setiap tahunnya mengalami peningkatan. Sebagian besar sumber penerimaan pajak dalam negeri berasal dari pajak penghasilan dengan rata-rata kontribusi $51,57 \%$ dari total penerimaan pajak untuk periode tahun 2007-2016. Pajak penghasilan orang pribadi merupakan salah satu instrumen yang digunakan untuk mengatasi ketimpangan distribusi pendapatan antara masyarakat yang berpenghasilan tinggi dan yang berpenghasilan rendah.

Gambar 2. Realisasi Penerimaan Negara (Milyar Rupiah), 2007-2016

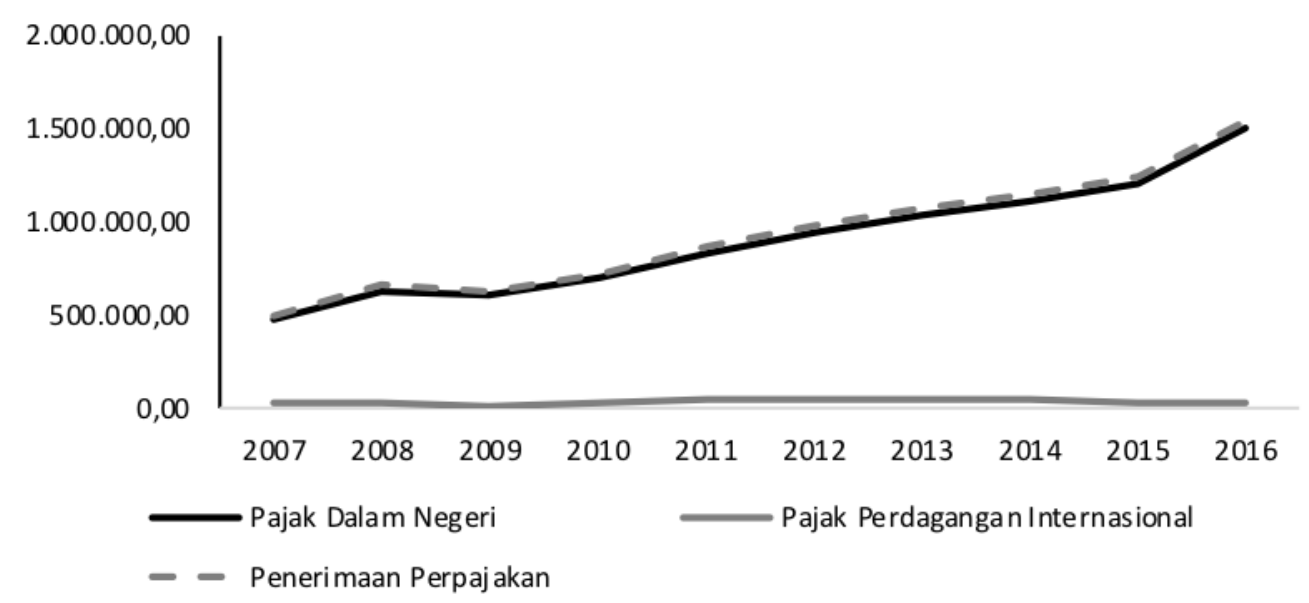

Sumber: diolah dari www.bps.go.id

Untuk mewujudkan fungsi distribusi pendapatan, tarif pajak penghasilan di Indonesia mengenakan tarif pajak progresif. Prinsip yang mendasari pajak progresif adalah bahwa masyarakat yang memiliki kemampuan lebih harus menanggung beban yang lebih besar dari total penerimaan pajak negara. Jadi masyarakat dengan penghasilan tinggi akan dikenakan tarif pajak yang lebih tinggi. Sebaliknya, masyarakat berpenghasilan rendah tidak hanya membayar lebih sedikit, tetapi mereka juga membayar pajak dengan persentase yang lebih rendah dari pendapatan mereka. Bahkan, masyarakat berpendapatan minim berpotensi tidak membayar pajak dengan adanya skema pendapatan tidak kena pajak. Pajak penghasilan 
progresif ini sejalan dengan tujuan mengurangi kesenjangan pendapatan sebagaimana temuan Office for National Statistics United Kingdom (2015). Lembaga tersebut mengkaji efek redistribusi pajak langsung dan tidak langsung serta program bantuan langsung tunai pada rumah tangga. Pajak penghasilan berhasil mengurangi kesenjangan pendapatan ditunjukkan dengan turunnya rasio gini sekitar 3,2 persen pada tahun 2015.

Faktor lain yang turut mempengaruhi kesenjangan pendapatan adalah jumlah penduduk. Menurut Bantika et al (2015), banyaknya jumlah penduduk menyebabkan lapangan kerja makin kompetitif. Sebagian tenaga kerja gagal memperoleh pekerjaan atau bekerja dengan tingkat upah yang rendah. Sehingga kenaikan jumlah penduduk dapat menyebabkan kesenjangan pendapatan semakin tinggi.

Berdasarkan latar belakang masalah dan beberapa literatur yang sudah diuraikan, penelitian ini ditujukan untuk menjawab pertanyaan penelitian, yaitu apakah pertumbuhan ekonomi, pajak penghasilan, pajak bumi dan bangunan, infrastruktur jalan, kualitas sumber daya manusia dan jumlah penduduk berpengaruh terhadap kesenjangan pendapatan?

\section{TINJAUAN PUSTAKA}

\section{Pertumbuhan Ekonomi}

Pertumbuhan ekonomi diartikan sebagai perkembangan kegiatan dalam perekonomian yang menyebabkan barang dan jasa yang diproduksi dalam masyarakat bertambah dan kemakmuran masyarakat meningkat (Sukirno, 2000). Meningkatnya pertumbuhan ekonomi menunjukkan barang dan jasa yang diproduksi bertambah sehingga kesenjangan pendapatan akan berkurang. Berdasarkan model pertumbuhan Solow, output perekonomian suatu wilayah hanya ditentukan oleh besarnya modal dan tenaga kerja dengan fungsi produksi berbentuk cobb douglas, yaitu:

dimana $\mathrm{Y}$ adalah pertumbuhan ekonomi, $\mathrm{K}$ adalah modal, dan $\mathrm{L}$ adalah tenaga kerja. Berdasarkan model tersebut, akumulasi modal berpengaruh langsung terhadap pertumbuhan ekonomi. Pada perkembangannya, pertumbuhan ekonomi suatu negara tidak hanya dipengaruhi modal fisik saja melainkan juga modal manusia. Perbedaan kualitas sumber daya manusia suatu daerah berdampak pada timbulnya perbedaan produktivitas yang kemudian berpengaruh terhadap kesenjangan pendapatan.

Tingginya pertumbuhan ekonomi yang salah satunya diukur dengan Produk Domestik Bruto (PDB) suatu negara belum tentu mencerminkan pemerataan distribusi pendapatan. Kenyataan menunjukkan bahwa pendapatan masyarakat tidak selalu merata, bahkan kecenderungan yang terjadi justru sebaliknya. Semakin tinggi tingkat pertumbuhan ekonomi, kesenjangan pendapatan semakin besar. Simon Kuznets berusaha menjelaskan hubungan antara pertumbuhan ekonomi dan pemerataan pendapatan melalui hipotesis kurva $\mathrm{u}$ atau "inverted u curve" seperti ditunjukkan pada gambar 3 (Todaro, 2000).

Gambar 3. Kurva Hipotesis Kuznets 


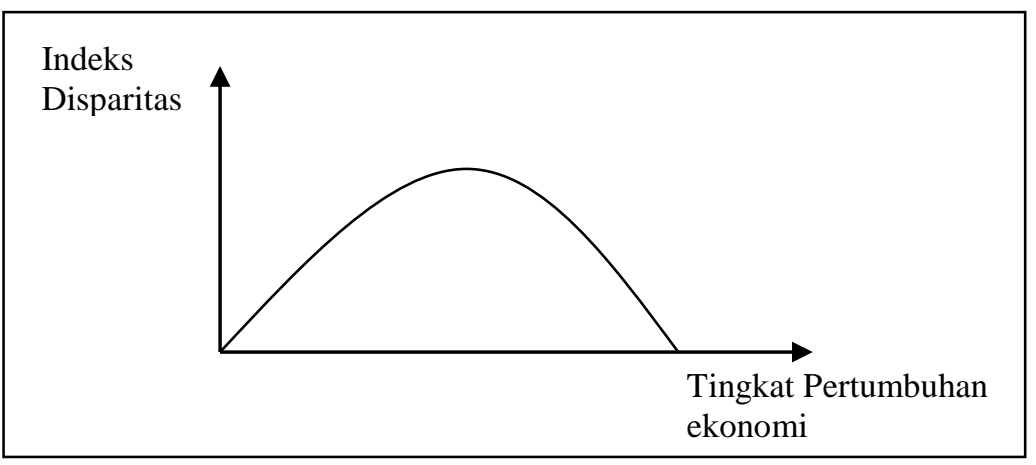

Sumber: Todaro (2000)

Kuznets berpendapat bahwa karakteristik awal dari sistem perekonomian suatu negara dapat menyebabkan perbedaan pertumbuhan pendapatan per kapita. Pada awal proses pembangunan, kesenjangan akan cenderung meningkat dan akan terus terjadi sampai mencapai titik puncak. Hal ini terjadi karena kesempatan dan peluang pembangunan yang ada umumnya dimanfaatkan oleh daerah-daerah yang kondisi pembangunannya sudah lebih baik, sedangkan daerah yang masih terbelakang tidak mampu memanfaatkan peluang ini karena keterbatasan prasarana dan sarana serta rendahnya kualitas sumber daya manusia. Setelah itu, bila proses pembangunan terus berlanjut, maka secara berangsur-angsur kesenjangan pembangunan akan menurun.

\section{Kesenjangan Pendapatan}

Kesenjangan pendapatan menggambarkan distribusi pendapatan masyarakat suatu daerah/wilayah pada kurun waktu tertentu. Pembagian pendapatan ditentukan oleh dua unsur, yaitu harga yang diperoleh untuk faktor produksi yang ditawarkan dan jumlah faktor produksi yang dimiliki atau dapat ditawarkan. Jadi, besar kecilnya pendapatan seorang tidak hanya bergantung pada harga atau besarnya balas-jasa yang diperolehnya, tetapi juga dari jumlah dan mutu faktor produksi yang dimiliki oleh berbagai lapisan masyarakat. Menurut Todaro dan Smith (2006), kesenjangan pendapatan akan menyebabkan beberapa hal, antara lain:

1. Kesenjangan pendapatan pendapatan yang ekstrem menyebabkan inefisiensi ekonomi

2. Kesenjangan pendapatan yang ekstrem melemahkan stabilitas sosial dan solidaritas

3. Kesenjangan pendapatan yang ekstrem umumnya dianggap tidak adil

Beberapa metode dapat digunakan untuk mengukur tingkat kesenjangan pendapatan, diantaranya kurva Lorenz, rasio Gini, indeks Theil, dan indeks Williamson. Pada penelitian ini, indikator kesenjangan pendapatan yang digunakan adalah rasio Gini yang mengukur ketidak merataan atau kesenjangan pendapatan/kesejahteraan secara agregat (keseluruhan). Nilai rasio Gini berkisar antara nol (pemerataan sempurna) hingga satu (kesenjangan sempurna). Untuk menghitung rasio Gini, digunakan rumus:

$$
\begin{aligned}
& G=1-\sum_{k=1}^{n}\left(X_{k}-X_{k-1}\right)\left(Y_{k}+Y_{k-1}\right) \\
& \text { dimana: } G \quad=\text { rasio Gini } \\
& X_{k} \quad=\text { proporsi kumulatif rumah tangga dalam kelas ke- } k \\
& Y_{k} \quad=\text { proporsi kumulatif pendapatan dalam kelas ke- } k
\end{aligned}
$$

Menurut Todaro (2000), pendapatan perkapita merupakan konsep yang paling sering digunakan sebagai tolok ukur tingkat kesejahteraan ekonomi penduduk di suatu negara.

Pemerintah dapat mengurangi ketimpangan dengan tiga cara, yaitu pajak, pengeluaran pemerintah, dan regulasi. Pajak adalah cara paling efektif, yaitu dengan menerapkan pajak 
progresif kepada golongan kaya untuk membiayai pengeluaran pemerintah dalam program sosial.

\section{Tinjauan Empiris}

Hipotesis Kuznets menyatakan hubungan antara pertumbuhan ekonomi dan pemerataan pendapatan berbentuk kurva U terbalik atau "inverted u curve". Temuan Thornton (2001) mengonfirmasikan hipotesis tersebut. Hasil regresi data panel yang dilakukan Thornton terhadap 96 negara menunjukkan bahwa hubungan antara ketimpangan pendapatan dan perkembangan ekonomi mengikuti pola kurva U terbalik, seperti yang dihipotesiskan Oleh Kuznets. Demikian juga temuan Oskooee dan Gelan (2008) di negara Amerika Serikat. Dengan menggunakan data time series, penelitian Oskooee dan Gelan menyimpulkan bahwa pertumbuhan ekonomi pada jangka pendek menyebabkan ketidaksetaraan pendapatan namun kesenjangan tersebut membaik pada jangka panjang. Oskooee dan Gelan menemukan, selain pertumbuhan ekonomi, faktor lain yang mempengaruhi kesenjangan pendapatan adalah pertumbuhan penduduk, sumber daya, ketidakstabilan harga, keterbukaan, devaluasi mata uang.

Murphy dan Topel (2016) melakukan penelitian mengenai investasi sumber daya manusia, kesenjangan, dan pertumbuhan ekonomi dari sisi penawaran tenaga kerja dimana pilihan sumber daya manusia dari individu mempengaruhi komposisi keterampilan di pasar tenaga kerja kemudian mempengaruhi harga keterampilan yang dimiliki tenaga kerja. Semakin baik kualitas sumber daya manusia, semakin tinggi harga keterampilan (tercermin dalam upah) yang dimilikinya. Sehingga Murphy dan Topel menyimpulkan bahwa peningkatan ketimpangan diakibatkan oleh kegagalan investasi modal manusia dalam mengimbangi meningkatnya permintaan akan keterampilan ketika perekonomian berkembang

Penelitian mengenai kesenjangan pendapatan di Amerika Serikat juga dilakukan Rubin dan Segal (2015). Hasil temuan mereka menunjukkan bahwa pendapatan kelompok berpenghasilan tinggi lebih sensitif terhadap pertumbuhan dibandingkan dengan pendapatan kelompok berpenghasilan rendah karena dua alasan: (a) kelompok pendapatan tinggi menerima sebagian besar pendapatan mereka dari kekayaan (aset) yang lebih sensitif terhadap pertumbuhan daripada pendapatan tenaga kerja dan (b) kelompok pendapatan tinggi menerima sebagian besar dari pendapatan tenaga kerja mereka dalam bentuk pay-forperformance (kompensasi ekuitas), yang juga sensitif terhadap pertumbuhan. Dengan demikian, mereka menyimpulkan bahwa pertumbuhan ekonomi dan kesenjangan pendapatan terkait secara positif.

Pemerintah melakukan upaya untuk mengurangi kesenjangan pendapatan dengan cara meredistribusi pendapatan. Instrumen yang digunakan berbagai negara untuk pemerataan pendapatan diantaranya pajak dan pengeluaran pemerintah. Untuk mengonfirmasi peranan pajak dan pengeluaran pemerintah dalam mengurangi kesenjangan pendapatan, beberapa peneliti kemudian melakukan kajian mengenai hal tersebut. Baer dan Galvao (2008) mengkaji keterkaitan antara beban pajak, pengeluaran pemerintah, dan distribusi pendapatan di Negara Brazil. Baer dan Galvao menemukan bukti yang kuat bahwa beban pajak dan pengeluaran pemerintah cenderung menguntungkan kelompok masyarakat dengan pendapatan yang lebih tinggi yang berarti kebijakan fiskal Negara Brazil memiliki dampak redistribusi yang rendah.

Di Negara Kanada, hasil penelitian yang dilakukan Kesselman dan Cheung (2004) menemukan bahwa sistem pajak secara substansial dapat memiliki dampak redistributif jika tingkat pajak keseluruhannya tinggi. Semakin besar penerimaan pajak, semakin besar potensi redistributif pada sisi pengeluaran publik. Belanja publik melalui barang dan jasa terutama dalam bentuk barang memiliki peran redistributif yang besar, terutama di bidang kesehatan dan pendidikan. 
Hasil penelitian lainnya disampaikan Office for National Statistics United Kingdom yang menyimpulkan bahwa variabel yang menyebabkan perubahan pada kesenjangan adalah tax credits, housing benefits, dan income support. Pajak langsung berpengaruh menurunkan kesenjangan pendapatan dalam jumlah yang kecil sementara pajak tidak langsung justru sebaliknya, meningkatkan kesenjangan. Sementara di Indonesia, Kumara (2015) menyimpulkan bahwa redistribusi melalui pajak (PPh dan $\mathrm{PBB}$ ) tidak mampu memperbaiki kondisi kesenjangan pendapatan. Hasil kajian Kumara juga menunjukkan adanya trade-off antara kemerataan pendapatan dan pertumbuhan ekonomi di Pulau Jawa dan dampaknya lebih besar pada kawasan high income. Namun pada kawasan low income, tidak ada trade-off antara keduanya. Baik kemerataan pendapatan dan pertumbuhan ekonomi dapat dilakukan bersamaan.

Bantika et al (2015) melakukan penelitian yang bertujuan untuk menganalisa faktorfaktor yang mempengaruhi ketimpangan pendapatan di Sulawesi Utara menggunakan analisis regresi linear berganda dan menyimpulkan bahwa luas lahan pertanian tidak berpengaruh signifikan terhadap indeks Gini, pertumbuhan ekonomi menurunkan indeks Gini, sedangkan penambahan jumlah penduduk meningkatkan indeks Gini di Sulawesi Utara. Tingginya jumlah penduduk menjadikan kompetisi dalam memperoleh lapangan kerja menjadi lebih ketat dan berdampak pada semakin tingginya kesenjangan.

Kajian lain mengenai kesenjangan pendapatan dilakukan Pradnyadewi dan Purbadharmaja (2016) di Provinsi Bali yang bertujuan untuk mengetahui hubungan secara langsung maupun tidak langsung variabel IPM, biaya infrastruktur serta investasi pada ketimpangan distribusi pendapatan. Karena setiap daerah memiliki kualitas sumber daya yang berbeda, menjadikan kualitas sumber daya manusia sebagai salah satu faktor yang mempengaruhi ketimpangan. Kualitas sumber daya manusia dapat dilihat dari Indeks Pembangunan Manusia (IPM) yang merupakan ukuran derajat perkembangan manusia dalam bidang kesehatan, pendidikan, dan kesejahteraan pembangunan. Semakin rendah IPM, tingkat produktivitas penduduk juga akan rendah dan berdampak pada rendahnya pendapatan. Hasil penelitian mereka menunjukkan bahwa terdapat pengaruh langsung dan signifikan IPM terhadap pertumbuhan ekonomi. Biaya infrastruktur dan pertumbuhan ekonomi mempunyai pengaruh langsung dan signifikan terhadap ketimpangan distribusi pendapatan. IPM dan investasi tidak memiliki pengaruh langsung dan signifikan terhadap ketimpangan distribusi pendapatan. Pertumbuhan ekonomi sebagai variabel intervening yang mempengaruhi IPM dan biaya infrastruktur secara tidak langsung terhadap ketimpangan distribusi pendapatan.

\section{METODE PENELITIAN}

\section{Jenis dan Sumber Data}

Penelitian ini bersifat kuantitatif dengan menggunakan data sekunder yang diperoleh dari Badan Pusat Statistik, Bank Indonesia, dan World Bank dengan periode pengamatan tahun 1990 sampai dengan 2015. Data yang digunakan meliputi laju pertumbuhan PDB riil, PDB atas dasar harga berlaku, rasio Gini, Indeks Pembangunan Manusia (IPM), Pajak Penghasilan, Pajak Bumi dan Bangunan, dan infrastruktur jalan.

Infrastruktur jalan dipilih karena tingkat pertumbuhan panjang jalan merupakan salah satu aspek penting infrastruktur regional yang dapat dikaitkan dengan kinerja dan pertumbuhan ekonomi (Del Bo, et. al, 2009). Investasi infrastruktur jalan dalam pembangunan ekonomi sangatlah penting untuk menjamin keterhubungan antar wilayah sehingga dapat memperlancar mobilitas faktor-faktor produksi, meningkatkan kualitas dan kuantitas sarana pembangunan, serta meningkatkan efisiensi pembangunan. Peningkatan konektivitas antara wilayah terpencil dan pusat-pusat pertumbuhan akan menyerap tenaga kerja lebih banyak dan memperbaiki aliran modal dari daerah kaya ke daerah miskin yang 
kemudian akan memperkecil kesenjangan pendapatan dan hasil-hasil pembangunan baik antar kelompok rumah tangga maupun antar wilayah.

\section{Alat Analisis}

Berdasarkan tinjauan teoritis dan empiris dengan mempertimbangkan keterbatasan data time series, model penelitian yang akan diestimasi adalah:

$$
G I N I_{t}=\alpha+\beta_{0} \ln (P D B)_{t}+\beta_{1} I P M_{t}+\beta_{2} P P h_{t}+\beta_{3} P B B_{t}+\beta_{4} J A L A N_{t}+\beta_{5} P N D K_{t}+\varepsilon_{t}
$$

\begin{tabular}{|c|c|c|}
\hline dimana: & GINI & $=$ rasio Gini \\
\hline & PDB & $=\mathrm{PDB}$ riil \\
\hline & IPM & $=$ Indeks Pembangunan Manusia \\
\hline & $\mathrm{PPh}$ & $=$ Pajak Penghasilan \\
\hline & PBB & $=$ Pajak Bumi dan Bangunan \\
\hline & JALAN & $=$ infrastruktur jalan \\
\hline & PNDK & $=$ pertumbuhan jumlah penduduk \\
\hline
\end{tabular}

Untuk variabel $P P h$ dan $P B B$, data yang digunakan untuk estimasi adalah rasio penerimaan PPh dan PBB terhadap PDB atas dasar harga berlaku. Sementara untuk variabel jalan diukur menggunakan pertumbuhan panjang jalan. Penggunaan ukuran fisik infrastruktur dalam model dipilih karena menurut Canning (1999) ukuran fisik lebih baik jika dibandingkan dengan penggunaan besarnya investasi pada infrastruktur. Hal ini disebabkan karena harga untuk investasi per satuan unit infrastruktur sangat bervariasi antara satu wilayah dengan wilayah lainnya. Di Indonesia, perbedaan ini sangat terlihat dari perbedaan harga untuk jenis pekerjaan yang sama di daerah yang berbeda karena letak geografis, kemudahan mencapai wilayah, jarak dari sumber material, dan sebagainya. Meskipun demikian, ukuran fisik infrastruktur tidak dapat mengoreksi secara penuh ukuran infrastruktur (Radiansyah, 2012).

\section{Hipotesis Penelitian}

1) Pertumbuhan ekonomi dan kesenjangan pendapatan

Hasil penelitian Oskooee dan Gelan (2008) menunjukkan bahwa pertumbuhan ekonomi pada jangka pendek menyebabkan ketidaksetaraan pendapatan. Demikian pula penelitian Rubin dan Segal (2015) yang menyimpulkan bahwa pertumbuhan ekonomi dan kesenjangan pendapatan terkait secara positif.

$\mathrm{H}_{1}$ : Pertumbuhan ekonomi berpengaruh positif terhadap kesenjangan pendapatan.

2) IPM dan kesenjangan pendapatan

IPM adalah indikator yang digunakan penelitian ini sebagai ukuran kualitas sumber daya manusia. Semakin baik kualitas sumber daya manusia, semakin tinggi tingkat pendapatan yang diperoleh. Namun keterbatasan pasar tenaga kerja menyerap tenaga kerja yang tersedia pada tingkat pendapatan yang lebih tinggi, menyebabkan tingkat pendapatan yang lebih tinggi hanya dinikmati oleh sebagian masyarakat.

$\mathrm{H}_{2}$ : IPM berpengaruh positif terhadap kesenjangan pendapatan.

3) Pajak penghasilan dan kesenjangan pendapatan

Pajak adalah salah satu instrumen yang digunakan pemerintah untuk mengurangi kesenjangan pendapatan. Semakin besar penghasilan seseorang, kewajiban pajak yang harus dibayarkan kepada pemerintah semakin besar pula. Semakin besar penerimaan pajak, semakin besar potensi redistributif pada sisi pengeluaran publik.

$\mathrm{H}_{3}$ : Pajak Penghasilan berpengaruh negatif terhadap kesenjangan pendapatan.

4) Pajak Bumi dan Bangunan dan kesenjangan pendapatan.

PBB termasuk dalam jenis pajak langsung, artinya beban pajak tidak dapat dialihkan kepada pihak lain sehingga pungutannya akan berdampak langsung pada subjek pajak. 
Hasil penelitian Office for National Statistics United Kingdom (2016) menyimpulkan bahwa pajak langsung berpengaruh menurunkan kesenjangan pendapatan.

$\mathrm{H}_{4}$ : Pajak Bumi dan Bangunan berpengaruh negatif terhadap kesenjangan pendapatan

5) Infrastruktur jalan dan kesenjangan pendapatan

Infrastruktur jalan dalam pembangunan ekonomi sangatlah penting untuk menjamin keterhubungan antar wilayah sehingga dapat memperlancar mobilitas faktor-faktor produksi. Peningkatan konektivitas antara wilayah terpencil dan pusat-pusat pertumbuhan akan menyerap tenaga kerja lebih banyak dan memperbaiki aliran modal dari daerah kaya ke daerah miskin yang kemudian akan memperkecil kesenjangan pendapatan dan hasil-hasil pembangunan baik antar kelompok rumah tangga maupun antar wilayah.

$\mathrm{H}_{5}$ : Infrastruktur jalan berpengaruh negatif terhadap kesenjangan pendapatan.

6) Jumlah penduduk dan kesenjangan pendapatan

Bantika et al (2015) menyimpulkan bahwa semakin tinggi jumlah penduduk menjadikan lapangan kerja semakin kompetitif dan menyebabkan kesenjangan pendapatan semakin tinggi karena tidak semua tenaga kerja dapat terserap.

$\mathrm{H}_{6}$ : Jumlah penduduk berpengaruh positif terhadap kesenjangan pendapatan.

\section{Metode Analisis}

Model penelitian dianalisis menggunakan regresi linear berganda untuk mengetahui pengaruh masing-masing variabel bebas terhadap pemerataan pendapatan. Langkah awal dalam analisis regresi linear berganda adalah menguji kelayakan model yang digunakan, yaitu dengan melakukan uji statistik F. Pada dasarnya hasil uji F menunjukkan apakah semua variable independen yang dimasukkan dalam model mempunyai pengaruh secara bersamasama atau simultan terhadap variabel dependen. Jika uji $\mathrm{F}$ menunjukkan hasil yang signifikan, untuk menunjukkan seberapa jauh satu variabel independen secara individual menjelaskan variabel terikat dilanjutkan dengan pengujian parsial regresi menggunakan uji t. sementara jika uji $\mathrm{F}$ menunjukkan hasil yang tidak signifikan maka tidak disarankan untuk melakukan uji $\mathrm{t}$ atau uji parsial. Berdasarkan hasil uji t, dapat dikonfirmasi apakah terdapat trade-off antara tingkat pertumbuhan ekonomi dan pemerataan pendapatan dengan melihat koefisien dari PDB.

\section{HASIL PENELITIAN DAN PEMBAHASAN}

Untuk mendapat hasil estimasi yang terbaik, sebelum dilakukan analisis terhadap model penelitian, dilakukan pengujian asumsi klasik terlebih dahulu, yaitu uji normalitas, uji multikolinearitas, uji autokorelasi, uji heteroskedastisitas. Prosedur tersebut perlu dilakukan untuk menguji asumsi-asumsi yang ada dalam pemodelan regresi linear berganda. Hasil pengujian asumsi klasik menunjukkan bahwa model penelitian ini terbebas dari masalah normalitas, multikolinearitas, autokorelasi, dan heteroskedastisitas. Hasil estimasi untuk model penelitian secara ringkas dapat dilihat pada tabel 1 .

Tabel 1. Hasil Estimasi Model Penelitian

\begin{tabular}{crrl} 
Variable & Coefficient & t-Statistic & \multicolumn{1}{c}{ Prob. } \\
\hline \hline PDB & 0.244144 & 8.263 & $0.000^{* * *}$ \\
IPM & $3.50 \mathrm{E}-05$ & 0.036 & 0.972 \\
PPH & 0.453351 & 1.766 & $0.093^{*}$ \\
PBB & 0.578619 & 0.175 & 0.863 \\
JALAN & 0.000273 & 0.168 & 0.868
\end{tabular}




$\begin{array}{crrl}\text { PNDK } & 0.133490 & 2.118 & 0.048 * * \\ \text { C } & -4.011516 & -7.152 & 0.000\end{array}$

\begin{tabular}{lr}
\hline \hline R-squared & 0.889 \\
Adjusted R-squared & 0.854 \\
F-statistic & 25.324 \\
Prob(F-statistic) & 0.000 \\
Durbin-Watson stat & 2.122
\end{tabular}

\footnotetext{
*** Signifikan pada $\alpha=1$ persen

** Signifikan pada $\alpha=5$ persen

* Signifikan pada $\alpha=10$ persen
}

\section{Sumber: output pengolahan EViews}

Koefisien determinasi dari model penelitian sebesar 0.85 menunjukkan bahwa variable independen mampu menjelaskan variasi kesenjangan pendapatan sebesar 85 persen. Hasil uji parsial terhadap masing-masing variabel independen menunjukkan bahwa terdapat tiga variabel yang signifikan mempengaruhi besarnya kesenjangan pendapatan antara golongan rumah tangga, yaitu variabel PDB, PPH, dan PENDUDUK. Berdasarkan hasil estimasi pada tabel 1, hubungan antar variabel penelitian yang dapat dinyatakan dalam bentuk persamaan struktural:

$$
\begin{gathered}
\text { GINI }_{t}=-4,0115+0,2441 \ln (P D B)_{t}+0,00003 I P M_{t}+0,4534 P P h_{t}+0,5786 P B B_{t} \\
+0,0003 J A L A N_{t}+0,1335 P N D K_{t}
\end{gathered}
$$

\section{Pertumbuhan ekonomi}

Berdasarkan hasil estimasi pada tabel 1, temuan penelitian ini sesuai dengan hipotesis awal yang diajukan yaitu bahwa pertumbuhan ekonomi berpengaruh positif terhadap kesenjangan pendapatan. Untuk setiap persen kenaikan pertumbuhan ekonomi, besarnya rasio gini akan meningkat sebesar 0.2441 persen dengan asumsi variabel lain konstan. Hal ini menunjukkan bahwa kondisi perekonomian Indonesia masih berada pada sisi kiri dari kurva "inverted $U$ curve". Artinya, kenaikan pertumbuhan ekonomi akan diiringi dengan tingginya kesenjangan pendapatan antar masyarakat. Temuan ini sejalan dengan hasil kajian Kumara (2015) yang juga menunjukkan adanya trade-off antara kemerataan pendapatan dan pertumbuhan ekonomi di Pulau Jawa. Begitu juga temuan Oskooee dan Gelan (2008) serta Rubin dan Segal (2015). Kondisi ini muncul karena pemerintah masih fokus mengejar pertumbuhan ekonomi. Di Indonesia, pertumbuhan ekonomi setiap provinsi tidak merata sebagaimana terlihat pada gambar 4 yang mengilustrasikan data sepuluh provinsi dengan rata-rata tingkat pertumbuhan ekonomi tertinggi selama periode 2010 sampai dengan 2015. Secara rata-rata pertumbuhan ekonomi tertinggi dicapai provinsi Sulawesi Tengah dengan tingkat pertumbuhan 9,91 persen diikuti Sulawesi Barat 8,63 persen. Namun kontribusi provinsi Sulawesi Tengah dan Sulawesi Barat terhadap pembentukan PDB Nasional hanya 0,82 persen dan 0,27 persen. Dari sepuluh provinsi dengan laju PDRB tertinggi, kontribusi total terhadap perekonomian nasional sebesar 10,75 persen. Hal ini menunjukkan bahwa tingginya pertumbuhan ekonomi daerah belum mampu mempersempit kesenjangan antar provinsi di Indonesia.

Gambar 4. Distribusi dan Laju PDRB menurut Provinsi 


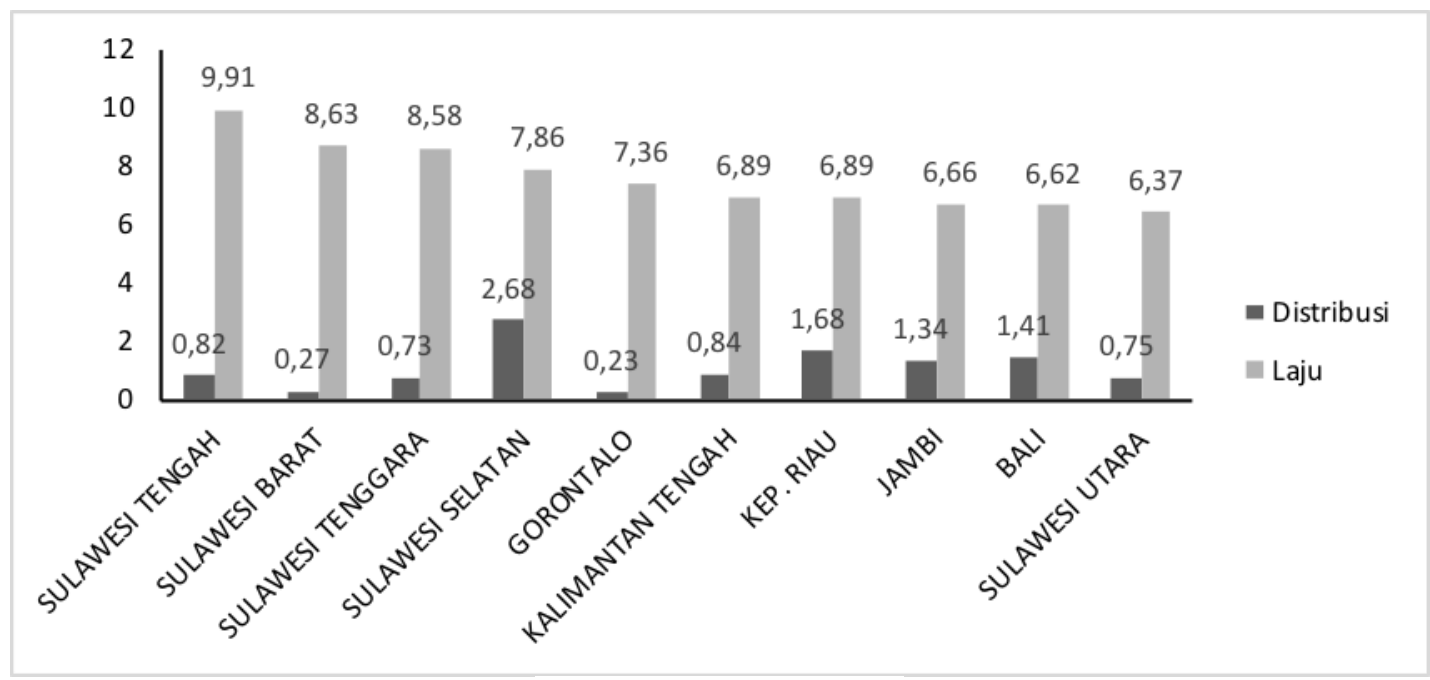

Sumber: BPS (diolah)

\section{Indeks Pembangunan Manusia}

Berdasarkan hasil estimasi, variabel IPM berpengaruh positif terhadap kesenjangan pendapatan tetapi secara statistik tidak signifikan. Temuan ini tidak sesuai dengan hipotesis yang diajukan dan berbeda dengan kesimpulan Murphy dan Topel (2016) namun sejalan dengan hasil penelitian Pradnyadewi dan Purbadharmaja (2016). IPM dibentuk oleh tiga dimensi dasar yaitu kesehatan, pendidikan, dan pengeluaran. Agregasi dari ketiga dimensi tersebut berdasarkan temuan penelitian ini tidak memiliki pengaruh yang signifikan terhadap kesenjangan pendapatan. Hal ini dapat terjadi karena kesenjangan pendapatan di Indonesia lebih disebabkan oleh kurang optimalnya pemberdayaan UMKM sebagaimana disampaikan oleh Menteri Koperasi dan UKM (Julianto, 2016). Menteri Perencanaan Pembangunan Nasional, Bambang Brodjonegoro juga menyampaikan bahwa salah satu faktor yang menyebabkan ketimpangan ekonomi adalah kualitas pekerjaan (Nugroho, 2017). Orang yang kurang terampil, akan terjebak pada pekerjaan dengan produktivitas dan upah yang rendah. Dengan demikian dibandingkan tingkat pendidikan, kualitas pekerjaan lebih berperan dalam menentukan perbedaan pendapatan antar masyarakat.

\section{Pajak penghasilan}

Hasil estimasi menunjukkan bahwa pajak berpengaruh positif dan signifikan terhadap kesenjangan pendapatan pada tingkat signifikansi 10\%. Koefisien variabel sebesar 0,4534 dapat diinterpretasikan bahwa untuk setiap persen peningkatan rasio penerimaan pajak penghasilan terhadap PDB dapat meningkatkan kesenjangan pendapatan yang diukur dengan rasio gini sebesar 0,4534 persen. Hasil penelitian ini sejalan dengan temuan Kumara (2015) yang menyimpulkan bahwa redistribusi melalui pajak ( $\mathrm{PPh}$ dan $\mathrm{PBB}$ ) tidak mampu memperbaiki kondisi kesenjangan pendapatan. Hal tersebut mungkin terjadi jika kebijakan perpajakan di Indonesia ditujukan untuk meningkatkan penerimaan negara, bukan sebagai alat untuk meredistribusikan kesejahteraan. Pemerintah Indonesia memiliki alternatif program redistribusi pendapatan selain pajak. Pertama, program pemberian jaminan akan akses kebutuhan primer di bidang kesehatan melalui BPJS Kesehatan. Kedua, program pemberian kredit lunak melalui KUR (Kredit Usaha Rakyat). Ketiga, Program Nasional Pemberdayaan Masyarakat Mandiri Pedesaan (PNPM Mandiri Pedesaan) yang diharapkan dapat mempercepat pemerataan pembangunan, penanggulangan kemiskinan, dan perluasan kesempatan kerja di daerah pedesaan.

Salah satu peran penting dari pemerintah adalah melakukan redistribusi pendapatan untuk mengoreksi kesenjangan ekonomi baik antar golongan pendapatan maupun antar 
wilayah. Pajak adalah instrumen yang paling efektif digunakan setiap negara untuk mendorong redistribusi pendapatan, salah satunya pajak penghasilan. Sesuai dengan Pasal 17 ayat 1, UU Pajak Penghasilan Nomor 36 tahun 2008, tarif pajak penghasilan pribadi perhitungannya menggunakan tarif progresif dimana setiap orang dikenakan pajak pada tingkat yang berbeda tergantung pada penghasilan yang diperoleh. Pajak penghasilan dipungut secara progresif sehingga penduduk dengan kategori high income membayar pajak lebih tinggi dibandingkan penduduk dengan kategori low income. Dengan demikian pendapatan masyarakat high income ditransfer dalam bentuk pajak untuk masyarakat berpendapatan rendah. Kesenjangan terjadi karena wajib pajak besar atau orang-orang kaya banyak yang belum patuh membayar pajak. Gambar 5 menunjukkan perkembangan rasio penerimaan pajak penghasilan terhadap PDB. Berdasarkan data Bank Indonesia, rasio penerimaan pajak penghasilan mulai tahun 2008 mengalami penurunan.

Gambar 5. Rasio Pajak Penghasilan terhadap PDB

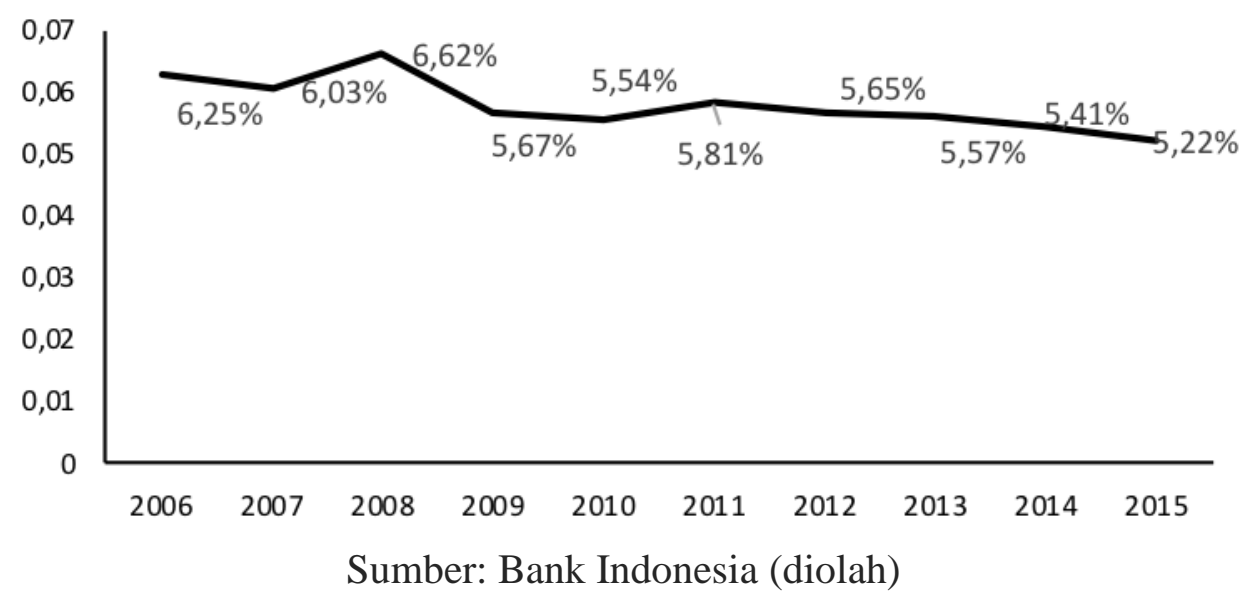

Pajak sebagai salah satu kebijakan fiskal pada dasarnya dapat menjadi instrumen distribusi ekonomi yang adil dan merata (Maftuchan, 2014). Namun menurut Maftuchan, praktik perpajakan di berbagai negara memperlihatkan bahwa pajak justru menjadi salah satu sumber penyebab terjadinya kesenjangan. Kajian Maftuchan menyimpulkan bahwa perpajakan menjadi salah satu sumber kesenjangan karena prinsip-prinsip keadilan dalam distribusi beban pajak pada berbagai golongan masyarakat tidak dapat berjalan. Selain itu, kelompok masyarakat kaya selalu melakukan langkah-langkah baik legal maupun ilegal untuk meminimalkan tanggungan pajak yang mereka miliki. Bambang Brojonegoro (Yudha, 2015) menyatakan bahwa salah satu pemicu tingginya kesenjangan pendapatan di Indonesia karena penghasilan dari orang-orang kaya di Tanah Air dinilai banyak yang belum tersentuh pajak untuk disalurkan kepada orang-orang miskin.

\section{Pajak Bumi dan Bangunan}

Hasil estimasi parameter menunjukkan bahwa variabel PBB secara statistik tidak menunjukkan pengaruh yang signifikan terhadap kesenjangan pendapatan. Temuan ini berbeda dengan hipotesis penelitian yang menyatakan bahwa PBB berpengaruh negatif terhadap kesenjangan pendapatan namun sesuai dengan kesimpulan yang disampaikan Kumara (2015). Hal tersebut dimungkinkan terjadi karena jumlah wajib pajak yang membayar pajak masih sangat sedikit. Sebagaimana diperlihatkan pada gambar 6, sejak tahun 2006 rasio penerimaan PBB terhadap PDB menunjukkan tren penurunan. Turunnya penerimaan PBB ini dinyatakan Direktur Jenderal Pajak Sigit Priadi Pramudito dalam Jati (2015) disebabkan turunnya daya beli masyarakat dan kegiatan pembangunan di dalam negeri 
sebagai dampak dari perlambatan ekonomi. Selain itu, diberlakukannya Peraturan Menteri Keuangan Nomor 267/PMK.011 tahun 2014 tentang Pengurangan Pajak Bumi dan Bangunan Sektor Pertambangan untuk Pertambangan Minyak Bumi dan Gas Bumi Pada Tahap Eksplorasi juga turut berkontribusi pada penurunan pertumbuhan PBB.

Gambar 6. Rasio Penerimaan Pajak Bumi dan Bangunan terhadap PDB

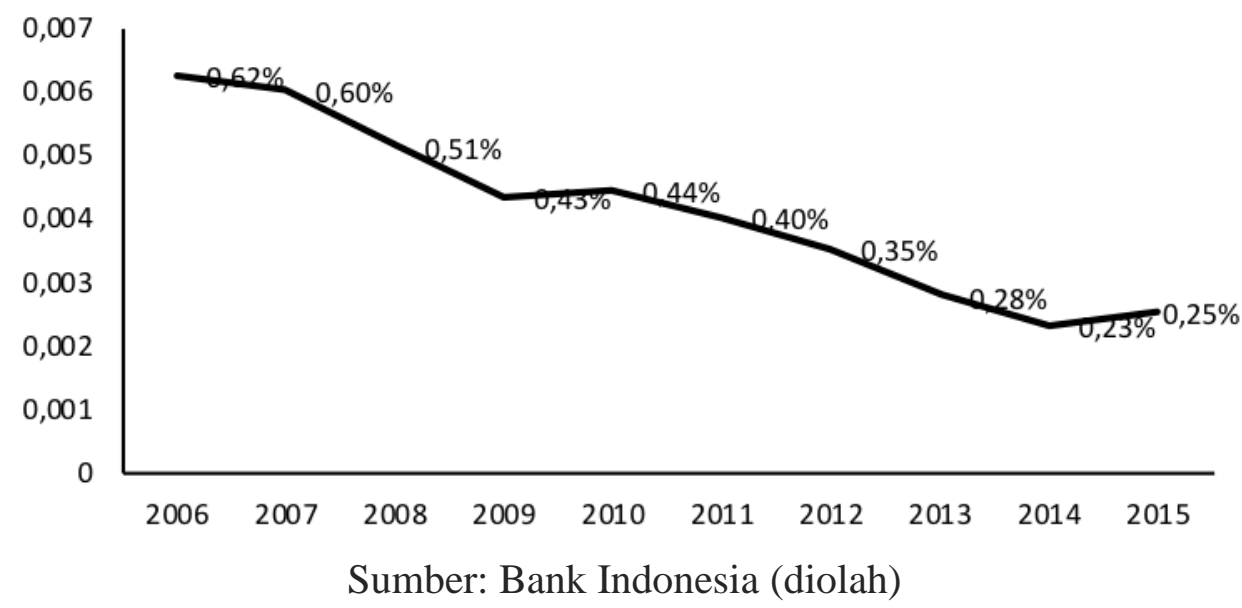

\section{Infrastruktur Jalan}

Hasil estimasi model penelitian menunjukkan bahwa variabel infrastruktur jalan menunjukkan pengaruh positif namun secara statistik tidak signifikan. Tidak signifikannya variabel jalan dimungkinkan terjadi karena kondisi infrastruktur jalan yang kurang menunjang konektivitas antar daerah. Infrastruktur jalan yang dimaksud dalam penelitian ini meliputi jalan nasional, jalan provinsi, dan jalan kabupaten/kota. Berdasarkan data BPS, total panjang jalan hingga tahun 2015 adalah $523.974 \mathrm{~km}$ dengan 42,48 persen diantaranya merupakan jalan bukan aspal. Distribusi jalan menurut kewenangan dapat dilihat pada gambar 7.

Gambar 7. Persentase Panjang Jalan menurut Kewenangan

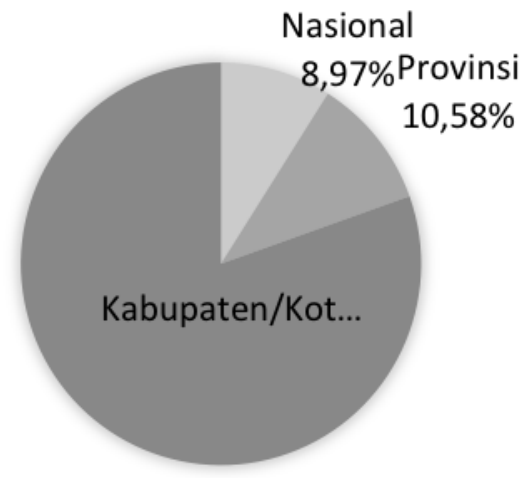

Sumber: BPS (diolah)

Dapat dilihat pada gambar 7, persentase panjang jalan nasional hanya 8,97\% dari total panjang jalan yang menunjang konektivitas antar wilayah di Indonesia. Untuk itu, perbaikan kondisi jalan selayaknya tidak hanya difokuskan pada jalan nasional saja tetapi juga jalan provinsi bahkan hingga kabupaten. Hal tersebut perlu dilakukan untuk mendukung aksesibilitas masyarakat yang tinggal di daerah pedesaan sehingga masyarakat di pedesaan dapat memperoleh fasilitas yang tidak jauh berbeda dengan masyarakat yang tinggal di perkotaan dan selisih barang/jasa antara satu daerah dengan daerah lainnya juga akan 
semakin berkurang. Perbaikan kondisi jalan nasional ditujukan untuk mendorong konektivitas yang semakin baik di sektor transportasi. Konektivitas transportasi memungkinkan wilayah-wilayah di penjuru Indonesia dapat dijangkau. Berbagai potensi ekonomi wilayah juga dapat dimaksimalkan dengan kemudahan mobilitas penduduk dari satu wilayah ke wilayah lain di Indonesia.

\section{Jumlah Penduduk}

Hipotesis yang diajukan pada penelitian ini menyatakan bahwa jumlah penduduk berpengaruh positif terhadap kesenjangan pendapatan. Temuan penelitian ini sesuai dengan hipotesis yang diajukan tersebut. Hasil estimasi parameter pada tabel 1 menunjukkan bahwa jumlah penduduk berpengaruh positif dan signifikan terhadap kesenjangan pendapatan. Untuk setiap persen peningkatan jumlah penduduk, besarnya rasio gini akan meningkat sebesar 0.1335 persen dengan asumsi variabel lain konstan. Hasil penelitian ini juga didukung oleh penelitian Bantika et al (2015) yang menyimpulkan bahwa penambahan jumlah penduduk meningkatkan indeks Gini di Sulawesi Utara. Tingginya jumlah penduduk menjadikan kompetisi dalam memperoleh lapangan kerja menjadi lebih ketat dan berdampak pada semakin tingginya kesenjangan. Jumlah penduduk yang besar menghasilkan angkatan kerja yang besar yang berpotensi meningkatkan pendapatan nasional namun memerlukan pembinaan dan pengembangan sumber daya manusia agar kualitas modal manusia mengalami perbaikan sebagai prasyarat untuk menuju tahap tinggal landas dari suatu perekonomian.

\section{SIMPULAN}

Hasil analisis terhadap model penelitian menunjukkan bahwa terdapat tiga variabel yang berpengaruh signifikan terhadap kesenjangan pendapatan, yaitu PDB, PPh, dan jumlah penduduk. Kondisi perekonomian Indonesia saat ini masih berada pada sisi kiri dari kurva "inverted $U$ curve". Tingginya PDB menyebabkan kesenjangan pendapatan semakin tinggi. Sehingga dapat dikatakan bahwa terdapat trade-off antara pertumbuhan ekonomi dan pemerataan pendapatan. Kondisi ini muncul karena pemerintah masih fokus mengejar pertumbuhan ekonomi. Salah satu instrumen yang digunakan pemerintah Indonesia yang juga populer digunakan negara-negara lain untuk mengurangi tingkat kesenjangan pendapatan adalah dengan menerapkan sistem pajak progresif salah satunya pada pajak penghasilan. Namun temuan dalam penelitian ini menunjukkan bahwa penerimaan pajak penghasilan berkorelasi positif dengan kesenjangan pendapatan. Redistribusi pendapatan melalui pajak tidak mampu memperbaiki kondisi kesenjangan pendapatan. Hal tersebut terjadi karena kebijakan perpajakan di Indonesia lebih ditujukan untuk meningkatkan penerimaan negara, bukan sebagai alat untuk meredistribusikan kesejahteraan. Kesenjangan juga terjadi karena wajib pajak besar atau orang-orang kaya banyak yang belum patuh membayar pajak. Perpajakan menjadi salah satu sumber kesenjangan karena prinsip-prinsip keadilan dalam distribusi beban pajak pada berbagai golongan masyarakat tidak dapat berjalan.

\section{IMPLIKASI DAN KETERBATASAN PENELITIAN}

Peningkatan pertumbuhan ekonomi yang tidak diiringi dengan pemerataan pendapatan memberikan keyakinan kepada kita bahwa pemerataan pendapatan seharusnya mendapatkan perhatian lebih saat ini. Kebijakan publik tidak hanya difokuskan pada peningkatan pendapatan nasional, tetapi harus mulai bergeser pada pengurangan tingkat kesenjangan pendapatan. Karena pajak merupakan instrumen penting yang digunakan pemerintah untuk meredistribusikan pendapatan, penerimaan pajak sebaiknya mulai diarahkan untuk program redistribusi kesejahteraan.

Penelitian ini memiliki beberapa keterbatasan, antara lain: 
1. Kesenjangan pendapatan yang dianalisa pada penelitian ini adalah kesenjangan pendapatan antar golongan masyarakat di Indonesia. Pada kenyataannya, kesenjangan terjadi tidak hanya antar golongan masyarakat saja, tetapi juga antar wilayah.

2. Infrastruktur yang dilibatkan pada penelitian ini hanya infrastruktur jalan, sehingga pada penelitian selanjutnya dipandang perlu untuk mempertimbangkan infrastruktur lainnya sebagai variabel yang mempengaruhi pemerataan pendapatan. Konektivitas antar wilayah yang mempengaruhi kinerja pertumbuhan ekonomi suatu daerah selain ditentukan oleh ketersediaan infrastruktur jalan juga infrastruktur lainnya seperti jembatan, bandara, pelabuhan, terminal, dan infrastruktur telekomunikasi. Selain itu, penelitian ini juga tidak mempertimbangkan sisi kualitas infrastruktur.

\section{DAFTAR PUSTAKA}

Badan Pusat Statistik. 2018. Statistik Indonesia 2018. Jakarta: Badan Pusat Statistik.

Baer, Werner dan Galvao, Antonio F. 2008. Tax Burden, Government Expenditures and Income Distribution in Brazil. The Quarterly Review of Economics and Finance Volume 48, Issue 2, May 2008, Pages 345-358.

Bantika, V., O. L. S. Benu, dan G. H. M. Kapantow. 2015. Faktor-faktor yang Mempengaruhi Ketimpangan Distribusi Pendapatan di Sulawesi Utara. Jurnal Ilmiah Fakultas Pertanian Universitas Samratulangi, Volume 6 Nomor 17.

Canning,D dan Pedroni, P. 1999. Infrastructure and Long Run Economic Growth. Consulting Assistance on Economic Reform II, Discussion Paper No. 57.

Del Bo, C. Florio, M dan Manzi, G. 2009. Regional Infrastructure and Convergence: Growth Implications In Spatial Framework. Milan European Economy Workshop, Working Paper No. 34.

Gudono. 2016. Analisis Data Multivariat. BPFE-Yogyakarta: Yogyakarta.

Jati, Gentur P. 2015. Dirjen Pajak Bongkar Alasan Penurunan Penerimaan Sampai April. https://www.cnnindonesia.com/ekonomi/20150506154033-78-51602/dirjen-pajakbongkar-alasan-penurunan-penerimaan-sampai-april/. Diakses tanggal 24 Juni 2017.

Julianto, P. Arhando. 2016. Menkop Ungkap Kesenjangan Pendapatan di Indonesia. https://ekonomi.kompas.com/read/2016/08/10/050000226/Menkop.Ungkap.Penyeba b.Kesenjangan.Pendapatan.di.Indonesia, diakses tanggal 17 November 2017.

Kementerian Keuangan. 2017. Reformasi Perpajakan untuk atasi Ketimpangan. http://www.kemenkeu.go.id/Berita/reformasi-perpajakan-untuk-atasi-ketimpangan. Diakses tanggal 29 Mei 2017.

Kesselman, Jonathan R dan Ron Cheung. 2004. Tax Incidence, Progressivity, and Inequality in Canada. Canadian Tax Journal, Vol. 52, No. 3, p. 709, 2004.

Kotlan, I dan Machova, Z. 2013. The Impact of the Tax Burden on the Living Standard in OECD Countries. Journal of Economics, vol.61 no. 9 (2013), p. 951-962.

Kumara, I. B. P. 2015. Keterkaitan antara Redistribusi, Ketimpangan Pendapatan, dan Pertumbuhan Ekonomi: Studi Kasus Kabupaten/kota di Pulau Jawa. Tesis. Institut Pertanian Bogor. 
Kuncoro. Mudrajad. 2002. Analisis Spasia dan Regional: Studi Aglomerasi dat Kluster Industri Indonesia. UPP AMP YKPN, Yogyakarta

Maftuchan, Ah. 2014. Ketimpangan Perpajakan di Indonesia: Pemetaan Awal Atas Area dan Pilihan Kebijakan untuk Mengatasinya. Jakarta: Perkumpulan Prakarsa (Welfare Initiative for Better Societies)

Murphy, K. M. dan R. H. Topel. 2016. Human Capital Investment, Inequality, and Economic Growth. Journal of Labor Economics, Volume 34 issue s2, pp: 99-127.

Nugroho, R. Aji. 2017. Ketimpangan Ekonomi di Indonesia, Menppenas: Ada Empat Penyebab. https://bisnis.tempo.co/read/907466/ketimpangan-ekonomi-di-indonesiamenppenas-ada-empat-penyebab/full\&view=ok. Diakses tanggal 8 Januari 2019.

Office for National Statistics. 2016. The effects of taxes and benefits on income inequality: 1977 to financial year ending 2015. United Kingdom.

Oskooee, M. B. dan A. Gelan. 2008. Kuznets inverted-U hypothesis revisited: a time-series approach using US data. Applied Economic Letters, Volume 15, issue 9.

Pradnyadewi, Diah T dan Ida Bagus Putu Purbadharmaja. 2016. Pengaruh IPM, Biaya Infrastruktur, Investasi dan Pertumbuhan Ekonomi terhadap Ketimpangan Distribusi Pendapatan di Provinsi Bali. E-Jurnal Ekonomi Pembangunan Universitas Udayana, Vol. 6, No. 2, Februari 2016 (pp. 255 - 285).

Radiansyah, D. 2012. Analisis Kontribusi Infrastruktur Terhadap Pertumbuhan Ekonomi Regional di Indonesia (PeriodeTahun 1996 s.d 2008). Jakarta. Tesis FEUI.

Rubin, A. dan D. Segal. 2015. The Effects of Economic Growth on Income Inequality in The US. Journal of Macroeconomics, Volume 45, September 2015, pages 258-273.

Sukirno, Sadono. 2000. Makro Ekonomi Modern : Perkembangan Pemikiran dari Klasik Hingga Keynesian baru. Raja Grafindo Pustaka.

Thornton, J. 2001. The Kuznets Inverted-U Hypothesis: Panel Data Evidence from 96 Countries. Applied Economic Letters, Volume 8, Issue 1.

Todaro, Michael P dan Smith, Stephen C. (2006). Economic Development, Ninth Edition . United States: Addison Wesley.

Todaro, Michael P. 2000. Economic Development. Addison-Wesley.

UNDP Indonesia. $2018 . \quad$ Tentang Indonesia. http://www.id.undp.org/content/indonesia/id/home/countryinfo.html. Diakses tanggal 9 Januari 2018.

Yudha, S. K. 2015. Kesenjangan Pendapatan Melebar karena Orang Kaya Malas Bayar Pajak. $\quad$ https://www.republika.co.id/berita/ekonomi/makro/15/12/13/nza9ji382kesenjangan-pendapatan-melebar-karena-orang-kaya-malas-bayarpajak?fb_comment_id=891044471016255_891052037682165. Diakses tanggal 27 Juli 2018. 